\title{
Corporate Payout Policy and Managerial Stock Incentives*
}

George W. Fenn

$183711^{\text {th }}$ St., Santa Monica, CA 90404

Nellie Liang

Board of Governors of the Federal Reserve System, Washington, DC 20551

First draft, March 1997, current draft March 1999

Abstract: We examine how corporate payout policy is affected by managerial stock incentives using data on more than 1100 nonfinancial firms during 1993-97. We find that management share ownership encourages higher payouts by firms with potentially the greatest agency problems - those with low market-to-book ratios and low management stock ownership. We also find that management stock options change the composition of payouts. We find a strong negative relationship between dividends and management stock options, as predicted by Lambert, Lannen, and Larcker (1989), and a positive relationship between repurchases and management stock options. Our results suggest that the growth in stock options may help to explain the rise in repurchases at the expense of dividends.

JEL Classification: G30; G32

Keywords: Dividends; Share repurchases; Executive stock options; Stock incentives

Correspondence to: George Fenn, $183711^{\text {th }}$ St., Santa Monica, CA, 90404, 310-664-1037, gfenn@alum.mit.edu; Nellie Liang, Federal Reserve Board, Stop 89, 20 ${ }^{\text {th }}$ and C Sts., NW, Washington, DC 20551, 202-452-2918, nliang@frb.gov.

* Earlier versions of this paper were titled "Good News and Bad News About Share Repurchases." The views expressed in this paper are those of the authors and not necessarily those of the Federal Reserve Board. We thank Stewart Myers, Manju Puri, and especially an anonymous referee for helpful comments, and Kyle Nagel, Mike Pizzi, Melissa Post, and Wendy Huang for outstanding research assistance. 


\section{Introduction}

Managerial stock incentives have the potential to help align the incentives of managers and shareholders. Hall and Liebman (1997) document that stock-based compensation has grown dramatically since 1980, suggesting that corporations regard stock incentives as being of practical importance. However, only a few studies investigate how managerial stock incentives influence management activities, and in particular, the extent to which they mitigate various agency problems. ${ }^{1}$

This paper investigates how corporate payout policy is affected by managerial stock incentives. We focus on payout policy because the free cash flow problem described by Jensen (1986) is one of the most severe agency conflicts between management and shareholders. It is one of managers deploying internally generated cash flow in a way that does not maximize shareholder wealth, and includes managers using internally generated funds to finance valuedestroying investments rather than returning funds to investors through dividends and share repurchases. An important question that we address is whether managerial stock incentives help to mitigate the free cash flow problem.

In principal, managerial stock incentives can influence payout policy in one of two ways. First, managerial stock incentives, by better aligning the interests of management and shareholders, may result in a higher level of total payouts. To the extent that greater alignment of management-shareholder interests through the use of stock incentives helps mitigate free cash flow problems, the level of repurchases and/or dividends may be positively related to management share ownership and stock options. This line of argument is similar to that of Mehran (1992) and especially Berger, Ofek, and Yermack (1997) who hypothesize that incentive compensation and management stock ownership, by mitigating conflicts between managers and shareholders, can lead to an increased and more optimal use of leverage.

${ }^{1}$ Among these are Berger, Ofek, and Yermack (1997) which examines how CEO stock and stock options influence the choice of leverage, Denis, Denis, and Sarin (1997) which examines how insider stock ownership affects corporate diversification, and Mehran, Nogler, and Schwartz (1998) which examines how CEO share ownership and stock options influence voluntary liquidation decisions. 
A second potential link is through the incentive to alter the composition of corporate payouts. The dramatic growth in recent years of share repurchases as a means of distributing cash to shareholders (see e.g., Jagannathan, Stephens, and Weisbach, 1998, and Weisbenner, 1998) suggests a fundamental change in corporate payout decisions that might be related to the growing use of managerial stock incentives. As first suggested by Lambert, Lannen,and Larcker (1989), executive stock options furnish management with the incentive to reduce dividends owing to the fact that the value of executive stock options, like all call options, are negatively related to future dividend payments. Consistent with this hypothesis, they document that dividends are reduced relative to expected levels following the adoption of executive stock option plans. The expected effect of management stock options on total payouts is uncertain: ceteris paribus, management will be indifferent between retaining the proceeds from a reduction in dividends or using them to repurchase stock, as the value of their call options will be the same in either case. However, to the extent that management aims to achieve a target payout level, option-induced reductions in dividends may be offset by increases in repurchases so that total payouts are largely unaffected.

To investigate how stock incentives affect the deployment of cash flow, we examine the relationship between payouts and stock incentives while controlling for measures of free cash flow. Our study uses data from Standard \& Poor's Execucomp database, which details data from company proxy statements on the amount of stock and stock options held by senior management for the universe of S\&P 1500 firms since 1992. Combining Execucomp with Compustat, we use data on more than 1100 nonfinancial firms to examine the determinants of open market share repurchases and dividends during 1993-97. We also examine determinants of total payouts-the sum of repurchases and dividends-and its composition during this period. An important feature of this analysis is the focus on long-term corporate payout policy, in contrast to much of the literature that focuses on factors that determine short-run policy or policy changes, such as the decision to repurchase stock in a given year or to increase dividends. In particular, we examine how firm characteristics influence average dividend and repurchase policy over a 3- to 5-year period. The advantage of this approach is that it abstracts from factors that may influence the timing of policy changes that are difficult for researchers to control for, e.g. companies 
repurchasing stock if they believe prices are too low or increasing dividends to signal higher earnings.

Our principal findings are these: First, management share ownership encourages higher payouts by firms with potentially the greatest agency problems-those with low market-to-book ratios and low management share ownership. However, we find no empirical evidence that higher levels of share ownership promote higher payouts for high market-to-book firms, or for firms with relatively high management ownership. We conclude that managerial stock incentives mitigate agency costs at companies with the most serious excess cash flow problems, but payouts at other firms are at the margin largely unaffected. We also find strong evidence that repurchases and dividends are strongly related to firm characteristics in a way consistent with the agency cost theoretic explanation of payouts. In particular, we document that repurchases and dividends are positively related to net operating cash flow and size and negatively related to market-to-book and leverage.

Second, controlling for free cash flow, stock option holdings change the composition of payouts. We find a strong negative relationship between dividends and management stock options, as predicted by Lambert, Lannen, and Larcker (1989). Our estimates imply that a one standard deviation change in the management stock option variable reduces dividend yields by an economically significant 38 basis points. We also find a statistically significant positive relationship between repurchases and management stock options, which together with the dividend results, suggest that stock options may help to explain the rise in repurchases at the expense of dividends.

A final set of results concerns the factors, in addition to stock options, that influence the choice between dividends and repurchases. The relationship of dividends and repurchases to our proxies for free cash flow are quite similar, suggesting that, over a horizon of several years, they are regarded as close substitutes. As noted, stock options tilt payout policy away from dividends and towards repurchases. Another factor that appears to affect the composition of payouts is the need for financial flexibility. We find that repurchases as a share of total payouts is positively related to the market-to-book ratio and to the volatility of operating income. These relationships are consistent with the hypothesis that firms with larger numbers of investment options and less 
predictable cash flow require greater financial flexibility, and hence rely more on opportunistic share repurchases rather than more obligatory dividends to disgorge cash flow.

Although the literature on corporate payouts-dividends and repurchases-is a large one, few studies have focused on agency cost-based explanations of payout policy. Smith and Watts (1992) document that industries with potentially the greatest agency costs-those with fewer growth opportunities-have higher dividend yields, suggesting that payouts are used as a bonding mechanism to control agency costs. They use data averaged over time (5-year increments) as well as by industry. Gaver and Gaver (1993) find similar results at the firm level using one year of data. With respect to share repurchases and agency costs, Bagwell and Shoven (1988) and Dittmar (1997) have tested for an empirical relationship between annual share repurchases and growth opportunities, proxied by a price-to-book, holding constant operating income. Both studies show that repurchases are positively correlated with operating income, and negatively related to price-to-book ratios, although Dittmar finds that the coefficient on price-to-book is not consistently negative over all the years in her sample. These papers assume implicitly an alignment of shareholders and management, and do not test directly what factors motivate firms to disgorge free cash.

Only a very few studies have examined directly the effect of managerial incentives and payout policy. Contrary to our results, Rozeff (1982) finds that dividend payouts are negatively related to insider stock holdings. He argues that insider stock ownership provides direct incentive alignment between managers and shareholders, while dividends serve as a bonding mechanism reducing management's scope for making unprofitable investment out of internal funds. Thus, insider stock ownership and dividend policy are viewed as substitutes means of addressing potential agency problems. This approach assumes that the optimal level of payouts is chosen conditional on stock incentives and begs the question of how the level of payouts is determined.

White (1996) examines the use of explicit mechanisms to encourage dividend payments_-provisions of executive compensation contracts that link executive bonuses to dividend payments. She finds that such provisions are more common where management stock ownership is lower and that such provisions result in higher dividend payments. Her findings 
implicitly suggest that management stock ownership encourages dividend payments, since the use of alternative mechanisms to encourage dividends is greater when management stock ownership is lower. But she does not investigate the relationship between dividends and stock ownership outside the context of the compensation provision, nor does she examine the role of stock options.

Jolls (1998), Bartov, Krinsky, and Lee (1998), and Weisbenner (1998) each use a discrete-choice framework to investigate the effect of employee or management stock options on a firm's choice between increasing dividends and repurchasing stock. Consistent with our results, each finds that the probability of repurchasing stock is positively related to stock options. Because none of these studies exploits data on quantities, they do not address the effect of stock incentives on total payouts, and only Jolls (1998) considers the role of stock ownership, and only restricted stock grants.

The remainder of our paper is organized as follows. In section 2 we describe our sample and data. In section 3 we present our main findings, discuss why stock options are not dividendprotected, and address alternative interpretations of our stock option results. Section 4 concludes.

\section{Sample and Data Description}

To investigate the relationship between corporate payout policy and managerial stock incentives, we use data from Standard \& Poor's Compustat and Execucomp databases.

Compustat is our source of our data for dividends, repurchases, and firm characteristics used as control variables while Execucomp is our source of data on managerial stock incentives. Because the Execucomp database begins with data for year-end 1992-the date at which new disclosure requirements for executive compensation became effective-our sample period covers dividends and repurchases made during 1993-97.

\subsection{Sample Selection}

To construct our sample we begin by merging Compustat with Execucomp which includes executive compensation data for firms in the S\&P 500, S\&P Midcap 400, and S\&P Smallcap 600 indices. We then eliminate annual observations that contain missing values for 
any of our variables as well as financial firms, utilities, and regulated telephone companies (SIC code 4813). ${ }^{2}$ This procedure yields 4987 annual observations with between one and five observations per firm. Next, because we want to focus our analysis on average payout policy over a horizon longer than one or two years, we eliminate all observations for firms for which there are only one or two annual observations in the merged data. We are left with a sample of 4663 observations for 1108 firms - 161 firms with three observations; 555 firms with four observations; and 392 firms with five observations. Because our unit of observation is firm-level averages (or standard deviation in the case of the volatility of operating income), our regression sample has 1108 observations.

\subsection{Payout Variables}

Our measure of dividend payout is regular cash dividends on common stock divided by the market value of common stock. To measure regular cash dividends we start with Compustat data item A21 (cash dividends - common). We then use Bloomberg to investigate all annual dividend payments that exceed 5 percent of the market value of stock and delete observations that involve special dividend payments (only 4 of the 4663 annual observations involve special dividend payments). ${ }^{3}$

For repurchase payout we use open market repurchases of common stock divided by the market value of common stock. To measure open market repurchases, we start with Compustat data item A115 (purchase of common and preferred stock). This item overstates open market repurchases of common stock for a number of reasons (Stephens and Weisbach, 1998; Jagannathan, Stephens, and Weisbach, 1998). First, it includes all other forms of common stock repurchases including self-tender offers and privately negotiated third-party transactions. Second, it includes repurchases of preferred stock. Third, it includes a variety of other transactions such as the conversion of other classes of stock into common stock.

\footnotetext{
${ }^{2}$ Financial firms are omitted for a variety of reasons, the most important of which is that Compustat does not report their stock repurchases. Heavily regulated firms (utilities and phone companies) are omitted because their payout policies may be significantly affected by their regulated status (Smith and Watts, 1992).

${ }^{3}$ The small number of special dividends that we find is consistent with DeAngelo, DeAngelo, and Skinner (1998) who find that special dividends have been used infrequently in recent years.
} 
As with dividends, we hand-check repurchases that exceed 5 percent of the market value of a firm's stock. In this case we use Dow Jones Interactive (all news sources) to determine whether a self-tender offer, privately negotiated transaction, or purchase or redemption of preferred stock has occurred. We believe that using a 5 percent cutoff allows us to identify most instances where overcounting would result from using Compustat data item A115. ${ }^{4}$ Using this procedure, we delete repurchase data for 65 of our 4663 annual observations. ${ }^{5}$

Table 1 reports descriptive statistics for payouts in our sample. Total payouts average 2.5 percent of the market value of common stock. Jagannathan, Stephens, and Weisbach (1998) report that the aggregate payout ratio for Compustat firms is approximately 3 percent during our sample period. We would expect their aggregate payout ratio-which is equivalent to a valueweighted average-to exceed the unweighted average reported in table 1 because payout ratios are positively correlated with firm size. In addition, our sample excludes utilities which pay high dividends. Payouts in our sample are almost evenly divided between regular cash dividends (1.3 percent) and open market repurchases (1.2 percent). Repurchases as a share of payouts average 47.8 percent.

Dividends and repurchases are positively correlated, but not highly so (table 2 ). Accordingly, the distribution of total payouts, appears less positively skewed than the distribution of either dividends or repurchases (figure 1).

\subsection{Management stock and stock option variables}

Our measure of managerial stock incentives are stock and stock options held by executive officers measured as a percentage of total shares outstanding. These data are reported in company proxy statements and are available through Execucomp. Other studies measure

${ }^{4} \mathrm{We}$ find that observations with the highest repurchase payouts typically involve transactions other than open market repurchases; conversely, we find that observations with payouts close to the bottom of the range that we investigate- 5 percent-usually do not involve such transactions.

${ }^{5}$ We delete the 4 dividend and 65 repurchase observations when forming firm-average payout variables. Another approach is to delete those firms from our sample, which reduces the sample size from 1108 to 1043 firms. The two approaches yield similar empirical results.

${ }^{6}$ In some cases data item A115 corresponds to repurchases net of equity issuance, which Compustat indicates with a combined figure code. We treat such observations as missing values. 
managerial stock incentives using equity ownership data for only the CEO (e.g. Berger, Ofek, and Yermack (1997) and Mehran, Nogler, and Schwartz (1998)) or equity ownership data for all corporate insiders including outside board members (e.g. Denis, Denis, and Sarin (1997)). Our choice of data owes to its availability in Execucomp; however, we believe it is reasonable to assume that corporate financial policy reflects the interests of all executive officers and not just those of the CEO.

Executive officers, on average, directly own 5.9 percent of the shares in their firms (table 1 , panel b). The shares underlying their options average 2.3 percent of company shares. While the average number of directly held shares is almost two-and-a-half times the average number of shares underlying stock options, the median number of shares held directly and underlying options are virtually identical at 1.6 percent. By contrast, Berger, Ofek, and Yermack (1997) report that the average CEO stock holdings for Forbes 500 firms during 1984-91 (2.7 percent) is over 15 times the average number of shares underlying CEO stock options ( 0.17 percent). The difference between the relative magnitude of stock and stock options in their sample and ours owes partly to the fact that their data includes only exercisable stock options while ours includes both exercisable and unexercisable options. However the difference likely also reflects the rapid increase in stock option awards in the last decade (Hall and Liebman, 1997). ${ }^{7}$

The distribution of directly held shares is highly skewed (figure 2). Although the median management ownership is 1.6 percent, 30 percent of the sample has management ownership greater than 5 percent and nearly 10 percent of the sample has management ownership greater than 20 percent. Morck, Shleifer, and Vishny (1988) observe that at sufficiently high levels of stock ownership managerial entrenchment may dominate the positive incentive effects of more direct alignment. As discussed below, we are careful to check the sensitivity of our empirical results to the inclusion and exclusion of firms with high management ownership.

${ }^{7}$ Jolls (1998) reports that the average number of options per executive officer in her sample (which covers fiscal year 1992) is 0.4 percent of shares outstanding. Her data, like ours, includes exercisable and unexercisable options. Assuming that the average number of executive officers covered in her proxy statements is between 4 and 5, her data imply an average holding by all officers of between 1.6 and 2 percent of shares outstanding, close to our sample average. 
Table 2 reports the sample correlations between payouts and managerial stock incentives for the full sample and a subsample of firms for which management ownership is less than 5 percent. In both the full sample and the subsample, the correlation between payouts and stock incentives is negative, most significantly in the case of dividends and stock options, consistent with the negative correlation between dividends and the use of incentive compensation plans reported by Smith and Watts (1992). The correlations involving management stock ownership appear sensitive to the inclusion of high ownership firms as they are somewhat stronger in the subsample than in the full sample. ${ }^{8}$

\subsection{Other explanatory variables}

Agency cost-based explanations of corporate payout policy imply that firms with high levels of excess cash flow and low marginal financing costs will have larger payouts. Firms with high levels of excess cash flow are at greater risk of overinvesting, and hence, derive greater benefits from distributing cash to shareholders. Firms with relatively low marginal financing costs can distribute more cash to shareholders knowing that if they must raise external funds in the future--because cash flow is lower than expected or profitable investment opportunities are greater than expected--the funds will be relatively inexpensive.

Conceptually, free cash flow is cash flow in excess of that required to fund all projects that have positive net present values (Jensen, 1986). Our proxies for free cash flow include EBITDA less capital expenditures, or net operating cash flow, scaled by assets. Other studies use operating income, or EBITDA, scaled by assets as a proxy for free cash flow. Its shortcoming is that it does not reflect the outlays necessary to undertake positive net present value investments. However, net operating cash flow may also misstate free cash flow if companies invest in negative net present value projects. As a practical matter, we obtain similar

\footnotetext{
${ }^{8}$ The correlation between direct stock ownership and stock options also appears sensitive to the inclusion of high-ownership firms: it is close to zero in the full sample $(\rho=0.03)$ but is significantly positive in the lower-ownership subsample $(\rho=0.34)$. The explanation for this result may be that both stock grants and stock options are awarded as part of incentive compensation programs; thus, among firms where incentive compensation accounts for the majority of management ownership, ownership and options are positively correlated. However, among high-ownership firms, ownership levels may reflect financing and ownership history more than the effects of stock incentive programs (i.e, a company may have been significantly financed and /or founded by the current management). For these firms, ownership and options will be less strongly correlated.
} 
results using either measure though specifications that include net operating cash flow consistently outperform those that include EBITDA. ${ }^{9}$

Our proxies for free cash flow also include a measure of investment opportunities. The most widely used measure of investment opportunities is the market-to-book asset ratio (see e.g. Smith and Watts, 1992, and Opler and Titman, 1993). Agency cost theories of corporate payouts predict a negative relationship between payouts and the market-to-book ratio.

Our proxy for external financing costs is firm size, measured as the log of assets. Larger firms are generally regarded as having more stable cash flows and posing less information asymmetries resulting in lower financing costs (Smith and Watts, 1992; Opler and Titman, 1993). We also control for leverage, although it is not exogenous. As leverage increases, the probability of financial distress, and hence, external financing costs increase. Debt is also an alternative method of disgorging free cash flow (Jensen, 1986; Berger, Ofek, and Yermack, 1997); thus, we expect that firms that rely more on debt to disgorge free cash will rely less on dividends and share repurchases.

Finally, we control for the volatility of operating income, measured as the standard deviation of EBITDA scaled by assets. Greater uncertainty about future levels of internally generated cash could increase the demand for precautionary holdings of cash and reduce the level of payouts (Jagannathan, Stephens, and Weisbach, 1998). Jagannathan et al. also suggest that uncertainty affects the composition of payouts, with firms with more uncertain cash flows favoring repurchases over dividends owing to their greater flexibility.

The distribution of these explanatory variables is summarized in table 1 (panel c). None of the variables appear to have significant outliers and no observations were truncated or excluded from the analysis.

\section{Empirical Results}

Our primary empirical results are reported in table 3 . We estimate four separate tobit regression models: one-sided tobit models for dividends, repurchases, and total payouts, which

\footnotetext{
${ }^{9} \mathrm{~A}$ third possibility is to use net operating cash flow less interest expense. This variable performs very similarly to net operating cash flow.
} 
are censored at zero, and a two-sided tobit model for repurchases as a share of payouts, which is censored at zero and one. In table 3 we report both marginal effects, evaluated at the mean of the explanatory variables, and marginal effects multiplied by a one standard deviation change in the explanatory variables. We multiply all quantities by 100 so that they correspond to percentage point changes in the dependent variable.

Turning first to the role of stock incentives, the effects of management stock and stock options on payouts appear to differ dramatically. As shown in row 1 of table 3 , there is no apparent link between share ownership and payouts: the estimated marginal effects of share ownership are almost identically zero in all four payout equations with p-values close to 1 . Thus, there appears to be little support for the hypothesis that stock incentives in the form of management stock encourage larger payouts in the full sample.

Conversely, management stock options appear to have very pronounced effects on payouts. As shown in row 2, a one standard deviation increase in stock options is estimated to reduce dividend payouts by 38 basis points (-0.38) and increase repurchases by 13 basis points $(0.13)$. These effects are consistent with the hypothesis that options alter the composition of corporate payouts by discouraging dividend payments. These estimates suggest that roughly onethird of the option-induced reduction in dividends is channeled towards repurchases with twothirds-25 basis points-retained by the firm. However, the relationship between total payouts and stock options suggest that total payouts decline only 13 basis points in response to a one standard deviation increase in stock options. Thus, our estimates suggest that between one-third and twothirds of option-induced reductions in dividends are redirected towards repurchases with the remainder retained by the firm. There is no evidence that stock options encourage larger total payouts.

The coefficients on the remaining explanatory variables in the payout regressions provide strong support for agency-based theories of payouts. In each of the three payout level regressions-dividends, repurchases, and total payouts-the coefficients on the four primary free cash flow variables have the predicted sign and are statistically and economically significant. For example, a one standard deviation increase in net operating cash flow leads to an estimated 50 and 55 basis point increase in dividends and repurchases, respectively, and to a 94 basis point 
increase in total payouts; a one standard deviation decrease in market-to-book increases dividends and repurchases by an estimated 47 and 35 basis points, respectively, and total payouts by an estimated 72 basis points. These estimated effects are equal to 30 to 40 percent of the sample mean payout levels. The impact of agency factors generally agrees with other studies, although the statistical significance of some of our estimates are higher than in other studies, suggesting that the role of agency factors may emerge more clearly using longer-term payout data. Market-to-book, for example, is not significant in Jolls (1998) or Weisbenner (1998), and only in some regressions in Dittmar (1997); they each use annual data.

The sign and magnitude of the regression coefficients in the dividend and repurchase regressions are quite similar. The similarity of the coefficients suggests that dividends and repurchases serve a similar function and that in many respects they are regarded as close substitutes. The repurchase share regression (fourth column) provides some further insight into the issue of substitutability. The mix of repurchases and dividends appears not to vary in any systematic way with net operating cash flow, size, or leverage. However, the payout mix does vary systematically with growth options, as proxied by market-to-book. This result is sensible to the extent that high market-to-book firms face not only more profitable investment opportunities, but also greater uncertainty about the level of profitable investment opportunities. With greater uncertainty, firms may require a more flexible payout policy and hence rely more heavily on repurchases than dividends.

The results for the volatility of operating income provide further evidence of the importance of flexibility. Increases in the volatility of operating income reduce dividends, in line with the flexibility hypothesis of Jagannathan, Stephens, and Weisbach (1998), and significantly increase the share of payouts made through repurchases.

We consider a number of alternative specifications to the basic model. We estimate specifications that include an interaction term between net operating cash flow and market-tobook to more accurately identify firms with high levels of free cash flow. As in Opler and Titman (1993), we construct a high-free cash flow dummy variable that indicates whether a firm simultaneously has both below-median market-to-book and above-median net operating cash flow; similarly, we construct a low-free cash flow dummy variable that indicates whether a firm 
simultaneously has above-median market-to-book and below-median net operating cash flow. Using these definitions, there are 185 high-free cash flow firms and 186 low-free cash flow firms in the full sample. ${ }^{10}$ When we add these dummy variables to the basic specification, their coefficients are generally of the predicted sign, though they are not large and only marginally significant. The marginal effect of the high-free cash flow dummy variable is 0.20 in the repurchase regression and 0.25 in the total payout regression with p-values of .07 and .12 respectively. The net operating cash flow and market-to-book variables remain highly significant with only slightly reduced marginal effects. Thus, we conclude that the variables in the basic specification adequately capture free cash flow. ${ }^{11}$

Because leverage is endogenous, leverage may be correlated with our regressions' error terms. For this reason, we re-estimate our primary regressions without leverage. The results from these regressions are not significantly different from those shown in table 3.

It is also possible that the relationship between leverage and marginal financing costs is u-shaped. Firms with little or no debt are that way because they are very risky and face high external financing costs. Conversely, firms with high leverage are near their debt capacity and face high external financing costs at the margin. Under these circumstances, the relationship between payouts and leverage may not be monotonic either; it may be positive at low levels of leverage, and negative elsewhere. ${ }^{12}$ To investigate this possibility we include a dummy variable that takes a value of one for firms in the lowest leverage quartile (debt / assets < 0.089). The ushaped hypothesis predicts a negative coefficient for this variable. Consistent with this hypothesis, the marginal effect of the low-leverage dummy variable is -0.25 and statistically significant in the repurchase regression ( $p$-value $=0.03$ ). This estimate implies that the repurchase payout of firms in the lowest debt quartile is 25 basis points less than otherwise. However, this variable enters insignificantly into the dividend and total payout regressions. We

\footnotetext{
${ }^{10}$ As these figures imply, the sample correlations between net operating cash flow and market-tobook are positive; thus, less than a quarter of the sample falls into either of these two groups.

${ }^{11}$ Of course, if we omit net operating cash flow and market to book, the high- and low- free cash flow dummies have the predicted signs and are highly significant.

${ }^{12} \mathrm{We}$ thank an anonymous referee for suggesting this possibility.
} 
conclude that mis-specification of our primary equations with respect to leverage likely is not a problem.

\subsection{A closer look at the effects of management share ownership}

As noted above, Morck, Shleifer, and Vishny (1988) argue that the relationship between management ownership and incentives is not positive throughout. They suggest that at ownership levels above 5 percent, managers may become entrenched, offsetting the positive incentive effects of having management's wealth tied to the value of the firm. Given that a substantial fraction of our sample has ownership greater than 5 percent, non-monotonicities could influence our results. To investigate this possibility we initially estimate the regressions in table 3 for the subsample of firms with ownership less than 5 percent. The coefficient estimates are virtually identical to those obtained for the full sample.

Ownership shares of 5 percent are still substantial, particularly in dollar terms; thus, marginal incentive effects at this level of ownership might be quite small. In addition, stock incentive effects may be important only in circumstances where free cash flow problems are most severe. A key measure of free cash flow is investment opportunities proxied in our data by market-to-book. To explore further the possibility that the full sample conceals important stock incentive effects present at firms with low levels of management ownership and the most severe potential free cash flow problems, we split the sample into four subsamples based on median values of management ownership and the market-to-book ratio and estimate our payout regressions for each of these subsamples.

Table 4 panel a reports the tobit estimates for the management stock variable for these subsamples. These estimates reveal major differences in the relationship between management stock and payouts for low- and high-market-to-book firms. For low market-to-book firms, total payouts are positively related to management stock and the relationship is statistically and economically significant. For low market-to-book firms that have low management ownership a one standard deviation increase in management stock (standard deviation over the subsample) increases payouts by an estimated 28 basis points ( $\mathrm{p}$-value $=.03$ ). Among low-market-to-book firms with larger management ownership, the sensitivity of total payouts to increases in management stock ownership is almost as great, 24 basis points ( $\mathrm{p}$-value $=.06$ ). These effects 
are on the order of 10 percent of the mean payout levels. Conversely, within the high market-tobook subsamples, the relationship between management shares and payouts is quantitatively small, sometimes negative, and highly insignificant. Our results are consistent with Lang and Litzenberger's (1989) finding that the wealth effects of dividend announcements are much larger for low-q firms than for high-q firms; with larger shareholder wealth effects for low-q firms, it follows that management stock furnishes stronger incentives.

Table 4 panel $b$ reports the results for a similar set of regressions using the dollar value of management stock ownership rather than management's ownership share as both the explanatory variable and to create the subsamples. The use of managers' percentage share ownership to measure incentive alignment is based on Jensen and Meckling (1976) who argue that incentives to waste corporate resources declines as management stock ownership percentage increases. Their analysis, which focuses on the supply of effort, implies that the ideal ownership percentage, from an agency cost perspective, is 100 percent. But as Hall and Liebman (1997) note, many, if not most, management decisions involve discrete choices. All that is needed for management to make value-maximizing decisions is that their utility from value-maximizing actions be higher than from alternative actions. Management's utility is as likely to be related to the market value of their shares as it is their percentage share ownership.

The motivation for splitting the sample by the dollar value of management stock is different than the motivation for splitting the sample by share ownership as in Morck, Shleifer, and Vishny (1988). We hypothesize that as management wealth in the firm increases, at some point the dollar value of the investment is adequate to assure that management deploys resources efficiently. At that point, further increases in management wealth in the firm does not have additional incentive effects. This point might be reached at low levels of ownership in a large firm or higher ownership levels in small firms. Whereas the Morck, Shleifer, Vishny hypothesis focuses on the entrenchment incentives that offset convergence-of-interest incentives, our hypothesis simply posits diminishing marginal incentives from additional management wealth holdings in the firm.

The results in panel $\mathrm{b}$ reinforce the importance of stock incentives in low market-to-book, i.e. low investment opportunity firms. For firms with low market-to-book and low management 
stock holdings, additional management stock significantly boosts repurchases and total payouts. A one standard deviation increase in management shares boosts repurchases by an estimated 27 basis points, and total payouts by an estimated 33 basis points. These estimates are statistically significant at the 0.01 level. However, in this case, management stock incentives are no longer important for low market-to-book firms with above-median management stock holdings. And, just as in panel a, high stock incentives are unimportant in high-market-to-book firms.

While the relationship between management stock and payouts varies significantly across subsamples, the estimated effects of management stock options on the composition of payouts-not shown-are highly robust to splitting up the sample. In all eight subsamples, stock options are negatively related to dividend payments, and the magnitudes of these relationships are comparable to that for the full sample. ${ }^{13}$ The relationship between total payouts and stock options is statistically insignificantly different from zero in all eight subsamples, suggesting that the effect of options on total payouts is, at most, small.

\subsection{Discussion of stock option results}

Our results strongly suggest that stock options affect the composition of payout policy, inducing a substitution away from dividends to share repurchases. In contrast to the incentive effects of management stock, which appear to exist only for certain firms, the incentive effects of management stock options appear to be strong for all firms. To understand why these effects are so pervasive, consider how the value of management stock options are affected by a decision to permanently lower a stock's dividend yield from 2.5 to 2 percent. ${ }^{14}$ Over the life of a ten-year option, such a decision results in lower dividends equal to 5 percent of the value of the firm (10 years times $1 / 2$ percent per year). Assuming that the average "delta" or price sensitivity of an option to the underlying share price is 50 percent, the decision to permanently reduce the dividend yield by $1 / 2$ a percent will result in an increase in option value equal to $2 \frac{1}{2}$ percent of the

${ }^{13}$ The estimated effect of a one standard deviation increase in stock options on dividend yields ranges from 20 to 51 basis points. All estimates are significant at the 0.01 level.

${ }^{14}$ This action could be undertaken without cutting the actual dividend; instead, the firm could simply not increase the dividend as much as it otherwise would have. 
share price. ${ }^{15}$ Thus, the management wealth effect that results from this relatively modest alteration in dividend policy equals or exceeds the average shareholder wealth effects that result from major dividend and open market repurchase announcements. ${ }^{16}$

Of course, the negative relationship between option values and dividend payments-and hence, management's incentive to reduce dividends-obtains only if options are not dividendprotected. However, the absence of dividend protection appears to be the norm. Cook (1987) reports that of the 193 Fortune 200 firms with stock option plans in 1986, only 9 had plans that included dividend-protection. Weisbenner (1998) documents that in his sample of 799 companies that granted stock options in 1994, only 2 offered dividend protection.

The most compelling explanation for not dividend-protecting options is related to their accounting treatment. Operationally, dividend-protection is accomplished through adjustments to an option's exercise price. Under current accounting standards, such options are considered to be variable-plan options because the strike price is contingent upon future events, and therefore the cost of these options must be recognized on the income statement as compensation expense. ${ }^{17}$

${ }^{15}$ This discussion relies on the approximation that the value of a call on a dividend-paying stock is equal to the value of a call on a nondividend paying stock with a stock price equal to the current stock price minus the present value of expected dividends over the life of the option (see Hull, 1989). We further assume that the expected rate of increase in the stock price (and hence, the dollar value of dividend payments) is equal to the rate used to discount future dividend payments. Management stock options typically are issued at-the-money; the delta of an at-the-money call is approximately 50 percent.

${ }^{16}$ For dividend increases, see e.g. Asquith and Mullins (1986) and Laux, Starks, and Yoon (1998); for open market repurchases, see e.g. Comment and Jarrell (1991), Ikenberry, Lakonishok, and Vermaelen (1995), and Stephens and Weisbach (1998).

${ }^{17}$ Current accounting standards are set out in the Statement of Financial Accounting Standards No. 123 Accounting for Stock Based Compensation (FAS 123), which was issued in October 1995 after years of intense debate. The main point of contention was whether compensation costs should be recorded for fixed-plan options granted at-the-money. The Financial Accounting Standards Board (FASB) yielded to pressures not to require that expenses be recorded, citing that the issues were so divisive that it threatened the FASB's working relationship with its constituents and the future of setting accounting standards. Thus, FAS 123 encourages but does not require that companies recognize the compensation expense for grants of stock options based on new fair value accounting rules. Companies that choose not to adopt the new rules will continue to apply the existing accounting rules contained in Accounting Principles Board Opinion No. 25, Accounting for Stock Issued to Employees. Since FAS 123 was issued, very few if any companies have adopted the fair value accounting rules. Instead, most continue to apply APB 25 to retain the favorable accounting treatment for fixed-plan options. 
In contrast, fixed-plan options-options for which the exercise price is known at the time of grant-never result in a compensation expense as long as the option is granted with an exercise price greater than or equal to the current market price. Thus, firms have a strong incentive to avoid variable-plan options in favor of fixed-plan options which do not allow for dividend protection.

An alternative explanation is that firms do not dividend-protect options for the express purpose of encouraging the substitution of repurchases for dividends. This argument assumes that at the margin shareholders have a stronger preference for repurchases vis-a-vis dividends than management. While shareholders might have a preference for repurchases owing to their tax efficiency it is difficult to think of reasons why management would have a preference for dividends. $^{18}$

While the option-induced substitution of repurchases for dividends appears to be widespread and can result in substantial ex-post management wealth effects, the impact on shareholders may nonetheless be quite limited. There are two ways in which management's substitution of repurchases for dividends could adversely affect shareholders. First, if the substitution resulted in a net reduction in payouts, such actions could increase the agency cost of free cash flow. As described above, we conclude that such reductions are small, at most. Second, to the extent that such substitution is not anticipated by shareholders, the reduction in dividends and increase in value of management stock options results in a wealth transfer from shareholders to management. (Conversely, if the shift in payout policy is anticipated, management's overall compensation package can be adjusted ex-ante so that its level of compensation is unaffected.) Offsetting these potential costs is the potential benefit of more taxefficient distributions even if encouraging tax-efficient distributions is not the motivation for issuing unprotected options.

\subsection{Alternative interpretation of stock option results}

It is possible that the relationships we observe between dividends, repurchases, and stock options are not the result of option-induced substitution, but rather, arise because options are

\footnotetext{
${ }^{18}$ Conceivably, if managers also hold large amounts of stock, they could have a preference for dividends as a means of cashing out a portion of their investment.
} 
correlated with unobservable characteristics of firms for which lower dividend payments are sensible. For example, as Smith and Watts (1992) argue, firms with many available growth opportunities may rely more heavily on stock options to provide management with the proper incentives when their investment decisions are difficult to monitor; alternatively, such firms may favor non-cash compensation in order to conserve cash. Such firms also would be expected to pay lower dividends. Furthermore, if stock options are primarily associated with uncertainty about the timing of investment opportunities, they could predict both lower dividends and higher share repurchases.

While we can never rule out these alternative interpretations, we have controlled for investment opportunities using market-to-book ratios and the estimated coefficients have the expected sign and are highly significant. Moreover, we find that the negative relationship between dividends and stock options is equally strong across subsamples of low market-to-book and high market-to-book firms. Of course, market-to-book may not be an adequate control for investment opportunities. Thus, we estimate our payout equations for the 185 firm subsample with below-median market-to-book and above-median net operating income described above. Even for these high-free cash flow firms-whose total payouts average 3.4 percent of firm value compared to 2.5 percent for our entire sample-we still observe a very strong negative relationship between dividends and stock options: a one standard deviation increase in stock options results in a 41 basis point decline in dividends (p-value $<0.01$ ). Thus, our results strongly suggest that options are not merely a proxy for growth opportunities.

\section{Conclusion}

This paper investigates how corporate payout policy is affected by managerial stock incentives. Using data for a sample of more than 1100 companies, we show that managerial share ownership furnishes incentives to increase payouts at companies with potentially the most severe agency problems - those with low market-to-book ratios and low management ownership. For high market-to-book firms management stock ownership has no effect on payouts at the margin; over a 3- to 5-year period, payouts for these firms appear to conform to agency-based theories of payouts, with the level of both dividends and repurchases increasing with free cash 
flow and decreasing with external financing costs. The mix of repurchases and dividends is determined in part by the need for flexibility, as hypothesized by Jagannathan, Stephens, and Weisbach (1998).

Management stock options have little effect on total payouts, but provide a strong incentive to reduce dividends and, in order to maintain payouts, boost share repurchases. While options may induce a more efficient corporate payout policy, shareholders may bear some costs if the shift to repurchases involves an unanticipated wealth transfer from outside shareholders to management. Whether shareholders recognize the costs of management stock options and reduce other forms of compensation to offset the increase in option values remains an open question. Even if they have not, shareholders may perceive the benefits of management stock options, such as the gains from the better alignment of manager and shareholder interests and the value created from retaining key employees, to more than offset these costs.

Our linkage of the choice of dividends and share repurchases to managerial stock incentives highlights a potentially important determinant of the surge in repurchases at the expense of dividends in recent years. Clearly, the November 1982 SEC ruling defining "safe harbor" conditions for open market repurchase programs, in combination with their greater flexibility, could help to explain the rising popularity of share repurchases. However, another fundamental change has been the growth in managerial stock incentives that encourages payouts by firms with high agency costs, and the increased use of employee stock options, which provide a direct incentive to reduce dividends. Consistent with this change, dividend growth has slowed and share repurchases have served the role of maintaining payouts. 


\section{References}

Asquith, Paul and David Mullins, 1986, "Signalling with Dividends, Stock Repurchases, and Equity Issues," Financial Management, 15, 27-44.

Bagwell, Laurie and John Shoven, 1988, "Share Repurchases and Acquisitions: An Analysis of Which Firms Participate," in Corporate Takeovers: Causes and Consequences. Univeristy of Chicago Press: Chicago, IL 191-213.

Bartov, Eli, Itzhak Krinsky, and Jason Lee, 1997, "Evidence on How Companies Choose Between Dividends and Open Market Stock Repurchases," Journal of Applied Corporate Finance, 11, 89-96.

Berger, Philip G., Eli Ofek, and David Yermack, 1997, "Managerial Entrenchment and Capital Structure Decisions," Journal of Finance, 52, 1411-1438.

Comment, Robert and Gregg Jarrell, 1991, “The Relative Signalling Power of Dutch-Auction and Fixed-Price Self-Tender Offers and Open-Market Share Repurchases," Journal of Finance, 46, 1243-1271.

DeAngelo, Harry, Linda DeAngelo, and Douglas Skinner, 1998, "Stock Repurchases and the Disappearance of Special Dividends," working paper, University of Southern California.

Denis, David J., Diane K. Denis, and Atulya Sarin, 1997, “Agency Problems, Equity Ownership, and Corporate Divesification," Journal of Finance, 52, 135-160.

Dittmar, Amy, 1997, "Stock Repurchase Waves and The Large Firm Effect," working paper, University of North Carolina Kenan-Flagler School.

Gaver, Jennifer J. and Kenneth M. Gaver, 1993, "Additional Evidence on the Association Between the Investment Opportunity Set and Corporate Financing, Dividend, and Compensation Policies," Journal of Accounting and Economics, 16, 125-160.

Hall, Brian J. and Jeffrey B. Liebman, 1997, “Are CEOs Really Paid Like Bureaucrats?,” NBER working paper 6213.

Hull, John, 1989, Options, Futures, and Other Derivative Securities, Englewood Cliffs, NJ:

Prentice-Hall.

Ikenberry, David, Josef Lakonishok, and Theo Vermaelen, 1995, "Market Underreaction to Open Market Share Repurchases," Journal of Financial Economics, 39, 181-208. 
Jagannathan, Murali, Clifford P. Stephens, and Michael S. Weisbach, 1998, "Financial Flexibility and the Choice Between Dividends and Stock Repurchases," working paper, University of Arizona.

Jensen, Michael, 1986, "Agency Costs of Free Cash Flow, Corporate Finance, and Takeovers," American Economic Review, 76, 323-329.

Jensen, Michael and William H. Meckling, 1976, "Theory of the Firm: Managerial Behavior, Agency Costs, and Ownership Structure," Journal of Financial Economics, 3, 305-360.

Jolls, Christine, 1998, “The Role of Incentive Compensation in Explaining the Stock-Repurchase Puzzle," Mimeo, Harvard Law School.

Lambert, Richard A., William N. Lanen, and David F. Larcker, 1989, "Executive Stock Option Plans and Corporate Dividend Policy," Journal of Financial and Quantitative Analysis, 24, 409425.

Lang, Larry H. P. and Robert H. Litzenberger, 1989, "Dividend Announcements: Cash Flow Signalling vs. Free Cash Flow Hypothesis,” Journal of Financial Economics, 24, 181-191.

Laux, Paul, Laura T. Starks, and Pyung Sig Yoon, 1998, “The Relative Importance of Competition and Contagion in Intra-Industry Information Transfers: An Investigation of Dividend Announcements," Financial Management, 27, 5-16.

Mehran, Hamid, 1992, "Executive Incentive Plans, Corporate Control, and Capital Structure," Journal of Financial and Quantitative Analysis, 27, 539-560.

Mehran, Hamid, George E. Nogler, and Kenneth B. Schwartz, 1998, "CEO Incentive Plans and Corporate Liquidation,” Journal of Financial Economics, 1998, 319-349.

Morck, Randall, Andrei Shleifer, and Robert W. Vishny, 1988, "Management Ownership and Market Valuation,” Journal of Financial Economics, 20, 293-315.

Opler, Tim and Sheridan Titman, 1993, "The Determinants of Leveraged Buyout Activitiy: Free Cash Flow vs. Financial Distress Costs,” Journal of Finance, 48, 1985-1999.

Rozeff, Michael S., 1982, "Growth, Beta, and Agency Costs as Determinants of Dividend Payout Ratios," Journal of Financial Research, 5, 249-259.

Stephens, Clifford and Michael Weisbach, 1998, "Actual Share Reacquisitions in Open-Market Repurchase Programs," Journal of Finance, 53, 313-334.

Smith, Clifford W. Jr. and Ross L. Watts, 1992, "The Investment Opportunity Set and Corporate Financing, Dividend, and Compensation Policies," Journal of Financial Economics, 32, 263-292. 
Weisbenner, Scott J., 1998, "Corporate Share Repurchases in the mid-1990s: What Role Do Stock Options Play," working paper, MIT.

White, Lourdes Ferreira, 1996, "Executive Compensation and Dividend Policy," Journal of Corporate Finance, 2, 335-358. 
Figure 1

Distribution of dividend, repurchase, and total payout

The sample includes 1108 firms in the S\&P 1500 during 1993-97 for which three or more years of data are available. Data are firm-level averages of annual observations. Dividend payouts are regular common stock dividends divided by the market value of common stock. Repurchase payouts are open market repurchases of common stock divided by the market value of common stock. Total payout is the sum of dividend and repurchase payouts.
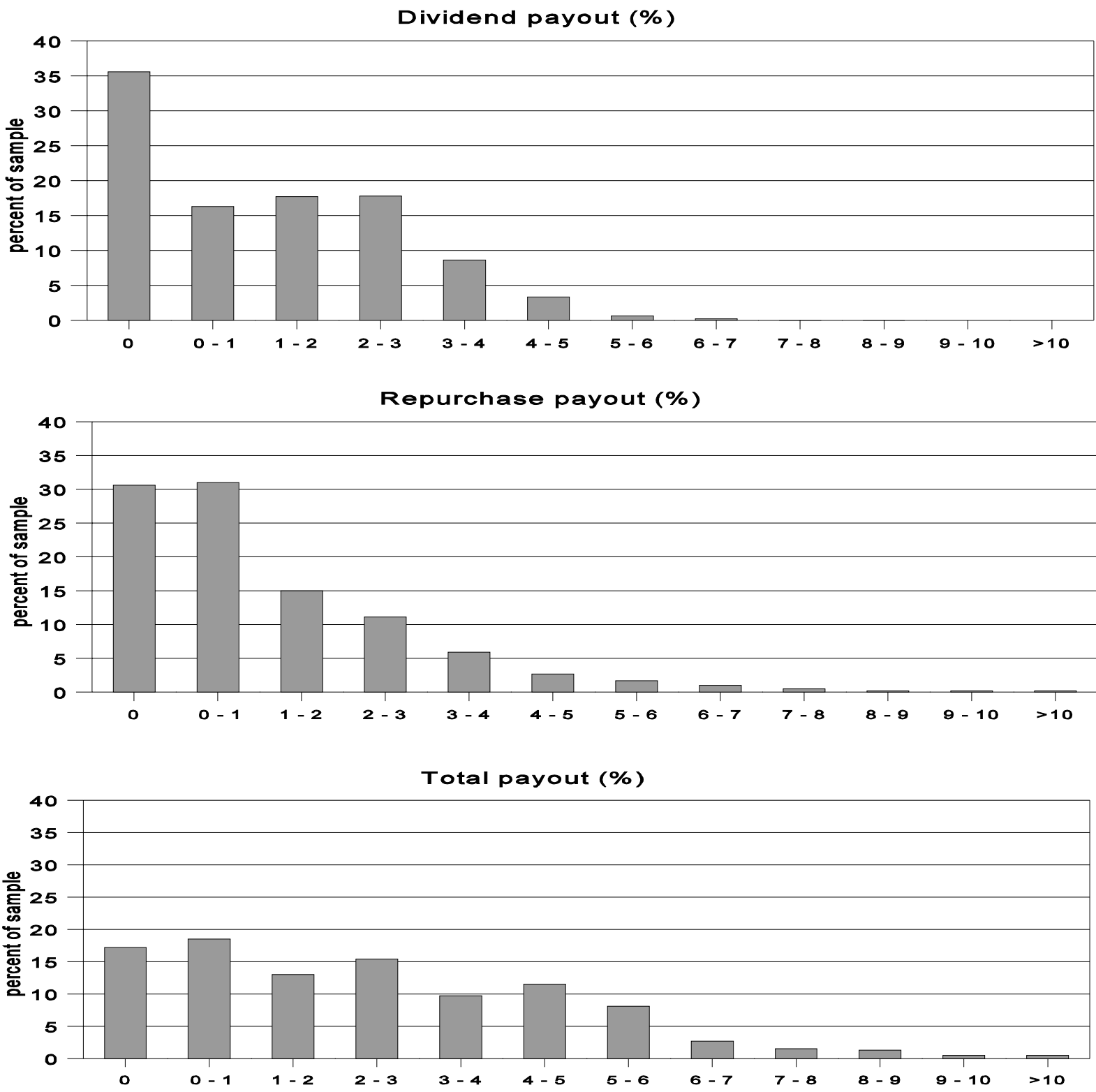
Figure 2

Distribution of management shares and options

The sample includes 1108 firms in the S\&P 1500 during 1993-97 for which three or more years of data are available. Data are firm-level averages of annual observations. Management shares are shares held by executive officers as reported in company proxy statements. Management options are shares underlying options held by executive officers as reported in company proxy statements
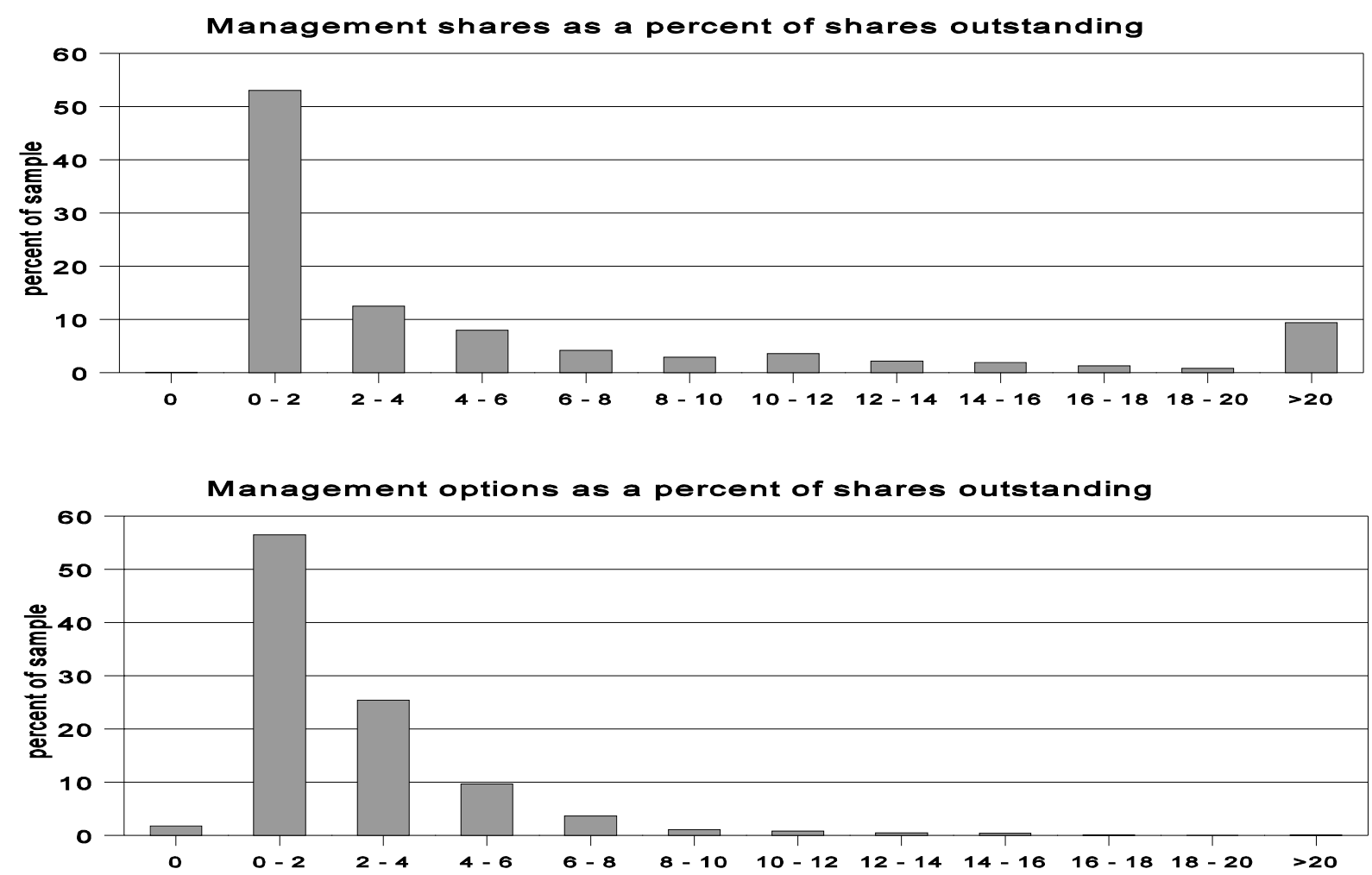
Table 1

Sample distribution of payouts, managerial stock incentives, and firm characteristics

The sample includes 1108 firms in the S\&P 1500 during 1993-97 for which three or more years of data are available. Financial firms, utilities, and regulated phone companies (SIC code 4813) are excluded. Dividends are regular cash dividends (Compustat item A13, corrected for special dividends using Bloomberg).

Repurchases are open market repurchases of common stock (Compustat item A115, corrected for self-tenders, privately negoatiated transactions, and purchase or redemption of preferred stock using Dow Jones Interactive). Market value is the market value of common stock. Management shares are shares held by executive officers as reported in company proxy statements. Management options are shares underlying options held by executive officers as reported in company proxy statements. Shares outstanding are shares of common stock. Net operating cash flow is operating income before depreciation (Compustat item A13) minus capital expenditures (Compustat item A128). Market-to-book assets is the market value of assets divided by the book value of assets, where the market value of assets is the book value of assets plus the market value of equity minus the book value of equity. Data are firm-level averages of annual observations except the volatility of operating income which is the firm-level standard deviation of annual observations.

\begin{tabular}{|c|c|c|c|c|c|c|c|}
\hline & & & \multicolumn{5}{|c|}{ Percentile } \\
\hline & Mean & s.d. & Min & $25^{\text {th }}$ & $50^{\text {th }}$ & $75^{\text {th }}$ & Max \\
\hline \multicolumn{8}{|l|}{ a. Payouts } \\
\hline Dividends / market value & 0.013 & 0.014 & 0.000 & 0.000 & 0.009 & 0.023 & 0.064 \\
\hline Repurchases / market value & 0.012 & 0.016 & 0.000 & 0.000 & 0.004 & 0.019 & 0.130 \\
\hline Total payout / market value & 0.025 & 0.023 & 0.000 & 0.003 & 0.021 & 0.041 & 0.146 \\
\hline Repurchases / total payout ${ }^{a}$ & 0.478 & 0.378 & 0.000 & 0.088 & 0.441 & 0.881 & 1.000 \\
\hline \multicolumn{8}{|l|}{ b. Management stock incentives } \\
\hline $\begin{array}{l}\text { Management shares / shares } \\
\text { outstanding }\end{array}$ & 0.059 & 0.098 & 0.000 & 0.004 & 0.016 & 0.065 & 0.805 \\
\hline $\begin{array}{l}\text { Management options / shares } \\
\text { outstanding }\end{array}$ & 0.023 & 0.024 & 0.000 & 0.007 & 0.016 & 0.031 & 0.222 \\
\hline \multicolumn{8}{|l|}{ c. Other explanatory variables } \\
\hline Net operating cash flow / assets & 0.074 & 0.109 & -0.752 & 0.037 & 0.080 & 0.127 & 0.830 \\
\hline Market-to-book assets & 1.748 & 1.196 & 0.162 & 0.997 & 1.384 & 2.078 & 10.969 \\
\hline Log of assets & 6.621 & 1.509 & 2.730 & 5.546 & 6.456 & 7.592 & 12.327 \\
\hline Debt / assets & 0.215 & 0.164 & 0.000 & 0.089 & 0.201 & 0.314 & 1.625 \\
\hline $\begin{array}{l}\text { Volatility of operating income / } \\
\text { assets }\end{array}$ & 0.037 & 0.040 & 0.001 & 0.015 & 0.025 & 0.043 & 0.575 \\
\hline
\end{tabular}


Table 2

Correlation of payout and managerial stock incentive variables

The full sample includes 1108 firms in the S\&P 1500 during 1993-97 for which three or more years of data are available. Financial firms, utilities, and regulated phone companies (SIC code 4813) are excluded. Dividends are regular cash dividends (Compustat item A13, corrected for special dividends using Bloomberg).

Repurchases are open market repurchases of common stock (Compustat item A115, corrected for self-tenders, privately negoatiated transactions, and purchase or redemption of preferred stock using Dow Jones Interactive). Market value is the market value of common stock. Management shares are shares held by executive officers as reported in company proxy statements. Management options are shares underlying options held by executive officers as reported in company proxy statements. Shares outstanding are shares of common stock. Data are firm-level averages of annual observations. p-values are in parentheses.

\begin{tabular}{|c|c|c|c|c|}
\hline & Dividends & Repurchases & $\begin{array}{l}\text { Management } \\
\text { shares }\end{array}$ & $\begin{array}{l}\text { Management } \\
\text { options }\end{array}$ \\
\hline \multicolumn{5}{|l|}{ a. Full sample $(n=1108)$} \\
\hline Dividends / market value & - & & & \\
\hline Repurchases / market value & $\begin{array}{l}0.16^{* *} \\
(0.000)\end{array}$ & - & & \\
\hline $\begin{array}{l}\text { Management shares / shares } \\
\text { outstanding }\end{array}$ & $\begin{array}{l}-0.12 * * \\
(0.000)\end{array}$ & $\begin{array}{c}-0.07 * \\
(0.014)\end{array}$ & - & \\
\hline $\begin{array}{l}\text { Management options / shares } \\
\text { outstanding }\end{array}$ & $\begin{array}{l}-0.35^{* *} \\
(0.000)\end{array}$ & $\begin{array}{l}-0.05 \\
(0.079)\end{array}$ & $\begin{array}{c}0.03 \\
(0.285)\end{array}$ & - \\
\hline \multicolumn{5}{|c|}{ b. Subsample with management shares $\leq 5 \% \quad(n=780)$} \\
\hline Dividends / market value & - & & & \\
\hline Repurchases / market value & $\begin{array}{r}0.14 * * \\
(0.000)\end{array}$ & - & & \\
\hline $\begin{array}{l}\text { Management shares / shares } \\
\text { outstanding }\end{array}$ & $\begin{array}{l}-0.25^{* *} \\
(0.000)\end{array}$ & $\begin{array}{l}-0.11^{* *} \\
(0.003)\end{array}$ & - & \\
\hline $\begin{array}{l}\text { Management options / shares } \\
\text { outstanding }\end{array}$ & $\begin{array}{l}-0.40^{* *} \\
(0.000)\end{array}$ & $\begin{array}{l}-0.07 \\
(0.053)\end{array}$ & $\begin{array}{l}0.34 * * \\
(0.000)\end{array}$ & - \\
\hline
\end{tabular}

** Statistically significant at 1 percent level

* Statistically significant at 5 percent level 
Table 3

\section{Tobit estimates of the determinants of corporate payouts}

The sample includes 1108 firms in the S\&P 1500 during 1993-97 for which three or more years of data are available. Data are firm-level averages of annual observations except the volatility of operating income which is the firm-level standard deviation of annual observations. One-sided tobits are used for the dividend, repurchase, and total payout regressions; a two-sided tobit is used for the repurchase share regression. All regressions are estimated with industry dummies. The first entry in the table is the marginal effect $\mathrm{x} 10^{2}$. The second entry is the marginal effect $\times 10^{2} \mathrm{x}$ the standard deviation of the explanatory variable. The third entry ( in parentheses) is the p-value of the marginal effect.

\begin{tabular}{|c|c|c|c|c|}
\hline & $\begin{array}{l}\text { Dividend } \\
\text { payout }\end{array}$ & $\begin{array}{l}\text { Repurchase } \\
\text { payout }\end{array}$ & Total payout & $\begin{array}{l}\text { Repurchase } \\
\text { share }\end{array}$ \\
\hline \multicolumn{5}{|l|}{ Managerial stock incentives: } \\
\hline 1. Management shares / shares outstanding & $\begin{array}{c}0.01 \\
0.00 \\
(0.96)\end{array}$ & $\begin{array}{c}0.11 \\
0.01 \\
(0.79)\end{array}$ & $\begin{array}{l}-0.09 \\
-0.01 \\
(0.89)\end{array}$ & $\begin{array}{c}1.28 \\
0.12 \\
(0.94)\end{array}$ \\
\hline 2. Management options / shares outstanding & $\begin{array}{l}-15.87 * * \\
-0.38 \\
(0.00)\end{array}$ & $\begin{array}{l}5.44 * * \\
0.13 \\
(0.00)\end{array}$ & $\begin{array}{l}-5.65^{*} \\
-0.13 \\
(0.04)\end{array}$ & $\begin{array}{l}761.69 * * \\
18.03 \\
(0.00)\end{array}$ \\
\hline \multicolumn{5}{|l|}{ Other explanatory variables: } \\
\hline 3. Net operating cash flow/ assets & $\begin{array}{l}4.54 * * \\
0.50 \\
(0.00)\end{array}$ & $\begin{array}{l}5.03 * * \\
0.55 \\
(0.00)\end{array}$ & $\begin{array}{l}8.63 * * \\
0.94 \\
(0.00)\end{array}$ & $\begin{array}{l}-2.79 \\
-0.30 \\
(0.90)\end{array}$ \\
\hline 4. Market-to-book assets & $\begin{array}{l}-0.39 * * \\
-0.47 \\
(0.00)\end{array}$ & $\begin{array}{l}-0.29 * * \\
-0.35 \\
(0.00)\end{array}$ & $\begin{array}{l}-0.60 * * \\
-0.72 \\
(0.00)\end{array}$ & $\begin{array}{l}4.51 * * \\
5.40 \\
(0.00)\end{array}$ \\
\hline 5. Log of assets & $\begin{array}{l}0.20 * * \\
0.30 \\
(0.00)\end{array}$ & $\begin{array}{l}0.26^{* *} \\
0.39 \\
(0.00)\end{array}$ & $\begin{array}{l}0.48 * * \\
0.72 \\
(0.00)\end{array}$ & $\begin{array}{l}1.73 \\
2.61 \\
(0.19)\end{array}$ \\
\hline 6. Debt / assets & $\begin{array}{l}-0.74 * * \\
-0.12 \\
(0.00)\end{array}$ & $\begin{array}{l}-1.60 * * \\
-0.26 \\
(0.00)\end{array}$ & $\begin{array}{l}-2.33 * * \\
-0.38 \\
(0.00)\end{array}$ & $\begin{array}{c}-13.73 \\
-2.26 \\
(0.23)\end{array}$ \\
\hline 7. Volatility of operating income / assets & $\begin{array}{l}-4.26 * * \\
-0.18 \\
(0.00)\end{array}$ & $\begin{array}{l}2.08 \\
0.08 \\
(0.12)\end{array}$ & $\begin{array}{l}-0.18 \\
-0.00 \\
(0.92)\end{array}$ & $\begin{array}{l}159.24 * * \\
6.44 \\
(0.01)\end{array}$ \\
\hline Number of observations & 1108 & 1108 & 1108 & 922 \\
\hline Mean of dependent variable $\times 10^{2}$ & 1.28 & 1.18 & 2.45 & 47.80 \\
\hline Log likelihood & 1722.9 & 1697.9 & 2063.6 & -777.3 \\
\hline $\begin{array}{l}* * \text { Statistically significant at } 1 \text { percent level } \\
* \text { Statistically significant at } 5 \text { percent level }\end{array}$ & & & & \\
\hline
\end{tabular}


Table 4

Tobit estimates for management stock variable using alternative measures within subsamples

In panel a, the tobit specifications used are the same ones used in table 3. In panel b, the tobit specifications used are the same ones used in table 3 except that log (dollar value of management stock) is used as the management stock variable. Median values of market-to-book (1.384) and management shares / shares outstanding (0.016) are used to create subsamples in panel a; median values of market-to-book and log (dollar value management stock) (2.620) are used to create subsamples in panel $\mathrm{b}$. The first entry in the table is the marginal effect $\mathrm{x} 10^{2}$. The second entry is the marginal effect $\mathrm{x} 10^{2} \mathrm{x}$ the standard deviation of the explanatory variable within the subsample. The third entry (in parentheses) is the p-value of the marginal effect.

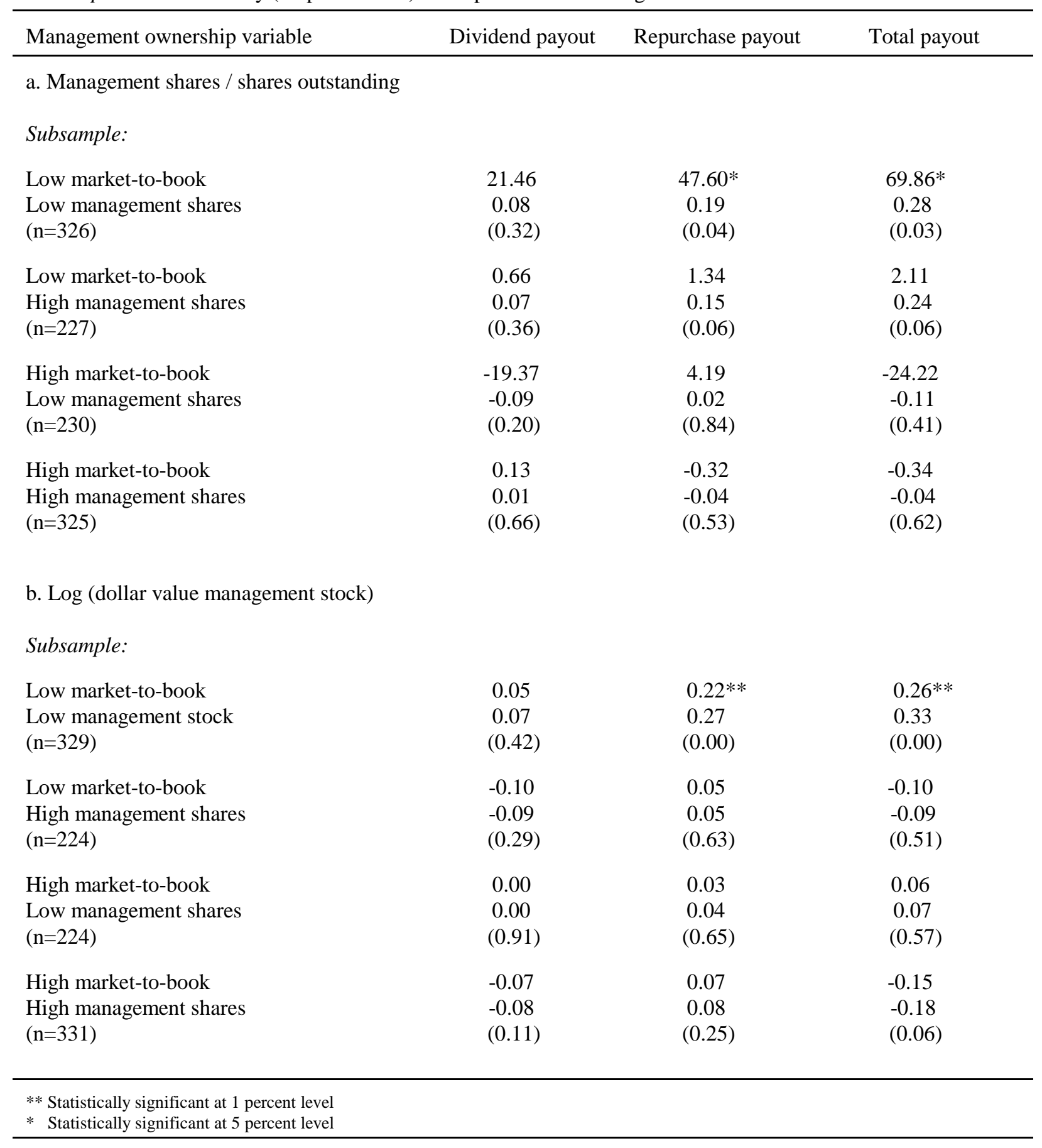

